International Journal of Current Aspects in Finance, Banking and Accounting, Volume 4, Issue 1, 2022 PP 91-103, ISSN 2707-8035

\title{
Socio-Economic Factors and Table Banking Loans Default Levels Among Women Groups in Machakos County, Kenya
}

\author{
Jeniffer Muendi Muthini ${ }^{1}$, Fredrick W. S. Ndede ${ }^{2}$ \\ ${ }^{1}$ Student, Master of Business Administration (Finance), Kenyatta University, Kenya \\ ${ }^{2}$ Department of Accounting and Finance, School of Business, Kenyatta University, Kenya
}

\begin{abstract}
Defaulting on a loan happens when one fails to make sufficient payments for an extended period. Lenders will deem a loan in default when the borrower haven't paid the minimum required payment for a certain number of months as detailed in the loan contract. Loan defaults can happen with any type of loan, table banking being one of them. In Kenya as in most developing countries, table banking has been recognized and accepted by development agencies and the government as effective tool for economic development poverty alleviation and industrialization. It's a proven method for women to spearhead their finances and experience economic perks through organized and calculated means. However, despite of their important role many of these table banking programs have collapsed because of problems in repayment. The general study objective was to investigate the effect of social economic factors on Table Banking loans default among Women in Machakos county, Kenya. The specific objectives were to determine the relationship between level of income, literacy level, borrowing experience as well as household demand and Table Banking loans default level among Women in Machakos County, Kenya. The study design was descriptive with a target population consisting of 22,500 women contained in all the 1500 women groups in Machakos County. A sample size of 384 women group members was selected through simple random sampling technique. Primary data on the selected women from the women groups were collected using structured questionnaires. The response rate was 342 women representing 89 percent. Data was analyzed using frequency distribution, chi-square tests and regression analysis. It was disclosed that there was a negative but significant association between level of income, literacy level, borrowing experience and household demand and table banking loan default level by women in women groups. Demographic factors also had a negative but significant relationship with table banking loan default level among women in women groups in Machakos County. For practice the study recommended that: Firstly, women should engage in extra financial activities to increase their income level. Secondly the uptake of loans should be with the reason of income generation and not necessarily meeting the households' needs. This will ensure that the loans taken will be regenerated to assure repayment in time and minimize defaulting of the table banking loans. Thirdly the government should enhance entrepreneurship and financial management trainings including incorporating it through formal education. This study focused on socioeconomic factors influence on women's default table banking loans, therefore, other influential factors and disciplines should be studied to useful to reduce the defaulting of table banking loans. The study was limited in Machakos County. Low biasness can be attained for all the Kenyan women groups, therefore, a study focusing on other locations and larger spheres of the population of the study should be done, that is, in county, regional and national levels.
\end{abstract}

Key Words: Socio-Economic Factors, Table Banking, Loans Default Levels, Women Groups

DOI 10.35942/ ijcfa.v4i1.235 
International Journal of Current Aspects in Finance, Banking and Accounting, Volume 4, Issue 1, 2022 PP 91-103, ISSN 2707-8035

\section{Cite this Article:}

Muthini, J., \& Ndede, F. (2022). Socio-Economic Factors and Table Banking Loans Default Levels Among Women Groups in Machakos County, Kenya. International Journal of Current Aspects in Finance, Banking and Accounting, 4(1), 91-103. https://doi.org/10.35942/ijcfa.v4i1.235

\subsection{Introduction}

Table banking is a group-based funding strategy where members come together to save and borrow instantly on a given date in a month living a small amount for administrative purpose (Joywo, 2014). Kariuki (2014) states that, "on a given date in a month, members place their savings and loan repayments on the table and immediately borrow all the monies placed on the table except a small percentage for administration hence table banking." The concept matches Zanzibar's loan schemes and village savings and Grameen bank of Bangladesh's model (Kariuki \& Ngugi, 2014). This is an empowerment programme that takes care of small and micro enterprise owns seeking credit for financing their business but do not qualify to obtain from formal banks because of high rates of interest and lack of collateral. According to Vonderlack and Schreiner (2001) the population being unable to access production factors, particularly capital is among the factors hindering the achievement of development goals in less developed and developing countries hence limiting the peoples' entrepreneurial ability especially the poor. In this case, in a number of countries, women groups have emerged with the aim of addressing the mainstream and state-led formal financial system so that the poor who are not considered bankable because of risk perceptions and information asymmetry are reached. It is accepted widely that some weaknesses in developing capital markets can be compensated by women group programs which can also assist entrepreneurs with low incomes in improving their businesses hence raising the living standards (Mwobobia, 2016). Particularly, the likelihood of women group support programs promoting women entrepreneurs who do not have access to other assistance forms to be successful. Vonderlack \& Schreiner (20010 states that, the evolution of micro finance is a reflection of the failures of the credit market particularly the formal financial industry. Formal financial sector has shifted to small saving groups incorporating both credit and savings suggesting that simple loans and saving services can aid in improving poor people's welfare and particularly women.

In United States women group projects have shown features of the invention and of United States manufacturing employment, they have been found to be providing about 55\% (Keeble, 2007). Small Medium Enterprises are also considered to be contributing to like 37\% to county's GDP accounting to $52 \%$ of US based businesses. Britain increased female enterprise development and its developmental plan as an important step to solve the issues associated to economic activities. According to King \& McGrath (2012), women enterprises as a leading cause of economic growth and economic development has been acknowledged in job creation and poverty alleviation and are greatly directed towards smaller firms, because 98 percent of micro-enterprise businesses are owned by women. In Ghana, inadequate finance for women groups is affecting their expansion and nation's economic growth. Ghana's 2010 macroeconomic situation harshly constrained credit access by individual based sectors. Interest rates were increased by government borrowing and the private sector was pushed out of the financial market. To solve the financial challenges women face in women groups, the government had introduced numerous inventions using financial sector reforms and its monetary policy hence increasing lending of banks to the private. On the other hand, inadequate credit access, excessive collateral necessities and increased interest rates still position major challenges to the SMEs expansion (McGahan \& Porter, 2016). 
International Journal of Current Aspects in Finance, Banking and Accounting, Volume 4, Issue 1, 2022 PP 91-103, ISSN 2707-8035

In Kenya, informal banking groups such as the credit associations and village savings are preferred by individual women for social and economic needs since they charge friendly interest rates on borrowing and do not have the bureaucracies that formal banks have. Borrowers are thus able to repay their loans with no difficulties. Gugerty (2007) further observes that women get credit to meet household needs and to serve disasters or illnesses since they cannot afford insurance premiums. For example, in Machakos County, most of the women are members of table banking groups where small interest rates are charged on loans thus, they can access affordable loans for their businesses. The interests remain as part of the revolving fund and are divided as bonuses and dividends amongst the women at the end of the year depending on everyone's saving and borrowing capacity (Gugerty, 2007). Odame et al. (2002), despite the significant contribution of these women groups to economic development in Kenya, productivity of women is mostly constrained by inaccessibility to productive resources. According to Okunade (2007), deprivation women face in terms of agricultural production resource access is influenced by the socioeconomic characteristics of women which include women's level of education and credit access, access to extension information and cooperatives and decision-making powers. Ogato (2009) also argued that socio-economic factors of respondents affected the ability of women in accessing resources. This study hence sought to determine the effect of social economic factors influencing the default rate for Table Banking loans in Women groups, Mavoko Subcounty, Kenya.

\subsection{Statement of the problem}

Kariuki \& Ngugi (2014) state that, in Kenya, the development of Table banking was done by the Poverty Eradication Commission (PEC) as a tool for economic development poverty alleviation and industrialization. Though, the poverty alleviation rate is not fast since a number of these groups have collapsed because of problems of repayment of loans (Werre, 2014). According to Asetto (2014), achievement of vision 2030 by Kenya will not be possible if attention is not given to the collapse of these table banking groups. The loan default issue is perceived to be table banking groups' main driver (Werre, 2014). For instance, in 2017, Ndama Mavoko Welfare Society was observed to have a 200,000 outstanding loan which was attributed to loan defaultment by a few members. The same year, total arrears and defaults of Rich Mavoko women self-help group amounted to Kshs. 1.4 million which increased to 2.2 million in 2018. Addressing the problem is very crucial and therefore the need to carry out this study.

Past studies have been conducted but little covers the effect of socio-economic factors that influence the default rate for Table Banking loans in Women groups. Research on factors that influence SMEs' access to financing in Kiambu County was done by Mutiria (2017), Table banking groups were however not focused on. Oni, Oladele and Oyewole (2006) similarly analyzed factors that influence loan default among Ogun State Nigeria based poultry farmers, the borrower's education level, gender and income level were among the factors found to influence loan default, the study however did not indicate how these factors influenced table banking groups especially in Kenya. A study in Mwanza by Marcelina (2018) on assessing the social-economic factors' impact on loan repayment performance. Income level, financial literacy level and education level were found to be affecting performance of loan repayment. This study focused on loan default in Kenya. Further, in East Hararghe, Ethiopia, a study on factors affecting smallholder farmers' loan repayment performance was done by Sileshi, Nyikal and Wangia (2012) and found out that level of education and size of the household significantly affected loan repayment performance but failed to focus on Table banking groups in Kenya. The current study sought to 
International Journal of Current Aspects in Finance, Banking and Accounting, Volume 4, Issue 1, 2022 PP 91-103, ISSN 2707-8035

analyze effect of socio-economic factors that influence the default rate for Table Banking loans in Women groups, Machakos County, Kenya

\subsection{Study Objectives}

The general objective was to investigate the effect of socio-economic factors on Table Banking loans default among Women in Machakos County, Kenya.

The specific objectives:

i. Determine the effect of level of income on Table Banking loans default among Women in Machakos County, Kenya;

ii. Find out the effect of women financial literacy level on Table Banking loans default among Women in Machakos County, Kenya;

iii. Establish the effect of borrowing experience on Table Banking loans default among Women in Machakos County, Kenya;

iv. Find out the effect of household demand on Table Banking loans default in Women groups, Machakos County, Kenya.

\subsection{Literature Review}

\subsection{Theoretical Review}

A theoretical framework is a collection of interrelated concepts. Good research should be grounded on theory (Esper, Mentzer and Stank, 2008). Three theories guided this research: theory of informational asymmetry, theory of micro-loan borrowing rates and default and self efficacy theory.

\subsubsection{Theory of Informational Asymmetry}

According to Lown \& Morgan (2003), "information asymmetries arise when gaining information on the characteristics or on the behavior of the borrower are costly for the financial institution and this generate problems of allocation of loans to borrowers with undesirable characteristics such as a high level of risk or inability to take advantage of the loan." The bank's information production function is stresses by Brown and Zehnder (2006). Degryse \& Cayseele, (2000) posit that, banks obtain information advantage through screening and monitoring procedures hence allowing them overcome incentive and information problems between the borrower and the bank. Therefore, bank financing aids in overcoming asymmetric information problems through production and analysis of information and through designing loan contracts improving the incentives of borrowers but may have some costs.

Scoring methods for credit history interpretation have been adopted to solve the challenges in assessing credit and demographic data regarding one's current and past experience with credit (Lown \& Morgan, 2003). The estimated association between the probability of poor loan performance and data on an individual's credit histories on credit bureau reports is represented by a credit score. "In credit history scoring systems, prospective applicants receive a numerical score based on their individual credit history information; the score reflects the historic performance of loans extended to individuals with similar characteristics, individuals with identical credit scores may have received them for different reasons, but within the context of the credit scoring index, they are assessed to have equal likelihoods of the predicted behavior, that is, they are considered to pose the same credit risk" (Brown \& Zehnder, 2006). 
International Journal of Current Aspects in Finance, Banking and Accounting, Volume 4, Issue 1, 2022 PP 91-103, ISSN 2707-8035

\subsubsection{Self Efficacy Theory}

Self-efficacy is an individual generative capability including emotional, social and cognitive (Bandura, 1997). In the financial literacy context, the theory is associated to how an individual manages their capability of understanding financial services and products, to be better-literate to the various ever fluctuative and dynamic financial services and product. Various factors influence self-efficacy: physiological and affective state, verbal persuasion, vicarious experience or modeling and mastery experience (Bandura, 1997). Bandura (1997) describes the self-efficacy psychological process in affecting human functions: selective, ability of selecting behavior and the right environment, affective, occurs naturally and determine the emotional experiences of a person, motivational, optimistic thinking appering to accomplish that which was planned, and cognitive, allowing one to predict the current events that may affect the future. This theory will inform this study by explaining on the variable financial literacy which is used as a predictor of table banking loan default.

\subsubsection{Theory of Micro-Loan borrowing Rates and Default}

It was postulated by Cheung and Sundaresan in 2007. It involves a lending simple model with no collateral. The model follows three things that help the lender to enforce the loan contract that is; a punishment technology that imposes a finite cost on borrowers who default, peer monitoring by lending to a party, which is jointly-liable for the contractual provisions' fulfillment and monitoring to reduce the resource diversion from productive uses by the borrower. According to this theory peer monitoring plus limited monitoring by lenders is enough to minimize the chance of default to levels that are acceptable, if credible punishment cost exists. However, when monitoring is done in excess by lenders the borrowing cost increases which may lead to non-participation by borrowers. Cheung and Sundaresan (2007) assert that, "when loan size increases, then the chance of defaulting increases and the loan rates dramatically increase, unless the maturity of the loans is increased." This theory will help this study in understanding how the level of loan default may increase, which will aid table banking groups in their operations to minimize the chance of default to acceptable levels.

\subsection{Empirical Literature}

An overview of the factor relationship between level of income, women financial literacy level, borrowing experience, household demand and Table Banking loans default in Women groups is provided here.

\subsubsection{Level of income and Table Banking loans default}

A study in Kenya by Kosen (2011) on demographic characteristics' effect on loan performance. Four variables (borrowers' age, gender, education and income level) were regressed against bank performance level. It was disclosed that Kenyan commercial banks' loan performance and borrowers' income level had no relationship. Acquah and Addo (2011) studied determinants of Ghanian fishermen's loan repayment performance. 67fishemen were randomly selected and data obtained by an interview schedule. Based on the study, majority of the participants were experienced fishermen with high average income annually and were in the reproductive age range. Results from the empirical analysis showed that, of the interviewed participants, " $70.1 \%$ had delayed repayment which was partly because of low catch and fishmongers having high debts. The regression estimates revealed that repayment of loan went up with the loan amount, fishing experience duration, fishing income and years of education whereas the loan repayment amount 
International Journal of Current Aspects in Finance, Banking and Accounting, Volume 4, Issue 1, 2022 PP 91-103, ISSN 2707-8035

was negatively influenced by investment made and the age. The regression analysis disclosed that the loan repayment amount was significantly predicted by the investment amount made, loan and fishing income. An investigation in Akatakyiman Rural Bank Ltd -Komenda by Mensah (2012) explored risk factors influencing loan default repayment among clients. Secondary data on some variables was gotten from the bank's credit department. For the 4 years (2006-2010) duration, 100 observations are done. The dataset had 11 variables. It was revealed that loan type and security were significant variables besides education level, age, marital status and gender.

\subsubsection{Financial literacy among women groups and Table Banking loans default levels}

Ombongi (2015) undertook an investigation on how loan performance and clients' financial literacy in Kajiado County based Deposit Taking Microfinance Institutions were associated. DTMFs clients in the six Kajiado County based DTMFs were targeted. of DTMFs clientele in the 6 DTMFs in Kajiado County, 217 clients were selected as the sample using stratified sampling. Data was analyzed using regression and descriptive analysis. Quantitative data was evaluated using SPSS. It was established that loan performance and financial literacy related negatively and it was recommended that, in monitoring and administering loan defaulters, DTMFs should have loan systems in place. In a related study in Oyo State of Nigeria's Ogbomoso agricultural zone, Oladeebo (2008) explored the socio-economic factors that influence repayment of loans among small scale farmers. From the multiple regression analysis, it was indicated that loan repayment was influenced positively by the farmers' education level, farming experience duration with credit use and loan amount obtained. In Nigeria's Ogun State, Oni et al. (2005) studied the factors that influence loan default among poultry farmers; the probit model results disclosed that loan repayment default was significantly influenced by the farmers' Income and educational level $(\mathrm{P}<$ $0.05)$, farmers' age at $(\mathrm{P}<0.01)$ and flock size at $(\mathrm{P}<0.10)$ level.

\subsubsection{Table Banking loans default and Borrowing experience}

In the USA, logit model was used by Nitin and Shui-Yan (2002) in their study to associate various factors to loan default. It was indicated that loan repayment was significantly influenced by entrepreneurs' businesses and borrowing experience in a similar zip code as the lending agency at I and 5\% respective error levels. An investigation was done in Malaysia by Roslan and Abdkarim (2009) on loan repayment determinants among microcredit borrowers. The study targeted 2,630 participants from 86 Agrobank branches in Malaysia. In identifying the primary determinants influencing microcredit repayment, the probit and logit models were employed. The results indicated that repayment was significantly and negatively influenced by training, repayment period, amount of loan and business activity. Consequently, loan default probability was positively influenced by borrower's experience. Waweru (2010) studied factors influencing bank loans repayment: Nic bank limited case study. The study used qualitative and quantitative approaches and findings presented by descriptive statistics. The results disclosed that loan repayment was influenced both negatively and positively by demographic factors. Female loanees, older borrowers (by age) and high-income earners had a higher success in loan repayment. Repayment was positively influenced by duration and type of loan with lower default rate being recorded by long term loans as compared to medium and short-term loans. It was indicated that loan repayment was not influenced by borrowing experience level.

\subsubsection{Household demand and Table Banking loans default}

The done by Ugbomeh et al (2008) in Nigeria, examined loan repayment performance determinants among women self help groups and the findings demonstrated that women farmers' 
International Journal of Current Aspects in Finance, Banking and Accounting, Volume 4, Issue 1, 2022 PP 91-103, ISSN 2707-8035

loan repayment performance was significantly and negatively affected by household size, interest rates and women as household heads but significantly and positively affected by commitment to self-help groups and farm proceeds' price stability. An exploration on factors affecting smallholder farmers' performance on loan repayment in East Hararghe, Ethiopia was done by Sileshi, Nyikal and Wangia (2012). Respondents' socio-economic characteristics were described using descriptive statistics and the influencing factors of smallholder farmers' loan repayment performance were analyzed using the two-limit I obit model. The findings demonstrated that nondefaulter and defaulter households varied significantly in terms of total land, total annual income, livestock units, technical assistance, distance from credit source, credit use experience and education. Moreover, education level, social ceremonies, crop and livestock disease and off farm income associated systematically with loan repayment. Though, amount of loan, family size and age did not differ significantly between the non-defaulters and defaulters. In Anambra state in Nigeria, variables with significance bearing on credit repayment performance were identified by Arene (2012) using a regression analysis. Duration of farming experience, education level, income and loan size were statistically significant whereas household size and distance were not significant.

\subsection{Research Methodology}

A descriptive research design was deployed. The design allows problem formulation for more precise investigation (Kothari, 2006). The use of a descriptive design was deemed fit since it can be utilized to ascertain opinions, attitudes and factual information. Consequently, the study explained the extent to which socio-economic factors affected table banking default level among women in women groups. In this study the population was all table banking women groups in Machakos County. There are 2200 women groups in this County. The women groups recorded a total of 22,500 members as of 2018. Therefore, the target population was 22,500 women. The women groups' data was from self-help groups' registrar in Machakos County. Simple random sampling was used to obtain 384 women from the target populace of 22,500 members. The fisher et al, (2003) formula was deployed since the population was more than 10,000. Therefore, the sample size was 384 women group members drawn from the target populace. Primary data was obtained using a questionnaire. A structured close ended questionnaire was used to collect the data. The quantitative data gathered was edited, coded, categorized and keyed into IBM SPSS for analysis for generation of descriptive and inferential statistics. Inferential statistics comprised of a multiple linear regression model while descriptive statistics comprised of frequencies and percentages. SPSS was complimented by Microsoft excel especially in tables and diagrams production. The variables' relationship was measured using the multiple linear regression models. The regression model helps in explaining the study variables' relationship direction and magnitude by using coefficients like significance level, determination coefficient and correlation.

\subsection{Data Analysis Results}

In an effort to determine the relationship strength between level of income, financial literacy level, borrowing experience and household demand and table banking loan defaults in women groups, a multiple regression analysis was undertaken. The results are in the succeeding parts. The model summary for the relationship between socio-economic factors and resultant effect on table banking loan defaults in women groups was illustrated. The results are shown in Table 1. 
International Journal of Current Aspects in Finance, Banking and Accounting, Volume 4, Issue 1, 2022 PP 91-103, ISSN 2707-8035

Table 1 Model summary

\begin{tabular}{ccccc}
\hline Model & R & R Square & Adjusted R Square Std. Error of the Estimate \\
\hline 1 & $.818 \mathrm{a}$ & 0.67 & 0.662 & 0.24233
\end{tabular}

a Predictors: (Constant), independent variables

Source: Research data (2022)

Table 1 indicate that the value of adjusted R squared was 0.662 implying that $66.2 \%$ of the table banking loan defaults in women groups could be explained by socio-economic factors (level of income, financial literacy level, borrowing experience and household demand). Some other factors not studied could explain the remaining $29.8 \%$ variation in table banking loan defaults. The ANOVA test was undertaken to examine the model's statistical significance. Table 2 shows the outcomes

Table 2 Regression ANOVA

\begin{tabular}{clccccc}
\hline Model & & Sum of Squares & df & Mean Square & F & Sig. \\
\hline \multirow{2}{*}{1} & Regression & 21.218 & 4 & 5.442 & 85.411 & $0.023 b$ \\
& Residual & 9.109 & 141 & 0.073 & & \\
& Total & 31.257 & 145 & & & \\
\hline
\end{tabular}

a Dependent Variable: table banking loan defaults

$b$ Predictors: (Constant), level of income, financial literacy level, borrowing experience, household demand

\section{Source: Field data (2020)}

Based on Table 2, the model is statistically significant with p-value $=0.013$ which implies that the independent variables (level of income, financial literacy level, borrowing experience and household demand) are usable in explaining the independent variable (table banking loan defaults) hence the model was adequate for further testing. Table 4.24 shows the regression coefficients.

Table 3 Coefficients of regression

\begin{tabular}{llccccc}
\hline \multirow{2}{*}{ Model } & & \multicolumn{2}{c}{ Unstandardized } & Standardized \\
Coefficients & Coefficients & $\mathbf{t}$ & Sig. \\
& & B & $\begin{array}{c}\text { Std. } \\
\text { Error }\end{array}$ & Beta \\
\hline $1 \quad$ (Constant) & 0.439 & 0.187 & & 2.395 & 0.023 \\
& Level of income & 0.282 & 0.042 & 0.355 & 7.056 & 0.011 \\
& Financial literacy & 0.257 & 0.043 & 0.332 & 5.945 & 0.001 \\
& level & 0.214 & 0.048 & 0.318 & 5.687 & 0.010 \\
Borrowing experience & 0.151 & 0.067 & 0.14 & 2.379 & 0.012 \\
\hline
\end{tabular}

a Dependent Variable: Table banking loan default rate

The summary of the model is shown in the equation.

Table banking loan default rate $(Y)=0.439+0.282 X_{1}+0.257 X_{2}+0.214 X_{3}+0.151 X_{4}$

Where $X_{1}$ is the Level of income, $X_{2}$ is financial literacy level, $X_{3}$ is Borrowing experience and $\mathrm{X}_{4}$ is the Households demands. According to the coefficients of regression in Table 4.10, Level 
International Journal of Current Aspects in Finance, Banking and Accounting, Volume 4, Issue 1, 2022 PP 91-103, ISSN 2707-8035

of income has a coefficient of 0.282 ( $\mathrm{p}$-value $=0.011$ ); and a t-value of 7.056. This implies that the Level of income have a positive and significant impact on table banking loan default rate. Similarly, Acquah and Addo (2011) studied determinants of Ghanian fishermen's loan repayment performance and the study results revealed repayment of loan increased with the loan amount, years of fishing experience, fishing income and years of education whereas the loan repayment amount was negatively influenced by investment made and the age. Acquah and Addo (2011) further showed that majority of the participants were experienced fishermen with high average income annually and were in the reproductive age range. Moreover, the loan repayment amount was significantly predicted by the investment amount made, loan and fishing income. Mensah (2012) explored risk factors influencing loan default repayment among clients and found that loan type and security were significant variables besides education level, age, marital status and gender.

Financial literacy level has a coefficient of 0.257 (p-value $=0.001$ ); and a t-value of 5.945. This implies that the Financial literacy level have a positive and significant impact on table banking loan default rate. Oladeebo and Oladeebo (2008) explored the socio-economic factors that influence repayment of loans and results showed that loan repayment was influenced positively by the farmers' education level, years of farming experience with credit use and loan amount obtained. Further, Oni et al. (2005) studied the factors that influence loan default among poultry farmers and disclosed that loan repayment default was significantly influenced by the farmers' Income and educational. Ombongi (2015) conducted a study on how loan performance and financial literacy of clients and found that loan performance and financial literacy related negatively and it was recommended that, in monitoring and administering loan defaulters, DTMFs should have loan systems in place

Borrowing experience has a coefficient of 0.214 (p-value $=0.010)$ and a t-value of 5.687. This implies that the Borrowing experience have a positive and significant impact on table banking loan default rate. Similarly, Roslan and Abdkarim (2009) assessed loan repayment determinants among microcredit borrowers and revealed that the borrower experience influenced the probability of loan default positively. On the contrary, Waweru (2010) in his study studied factors influencing bank loans repayment showed that loan repayment was not necessarily influenced by level of borrowing experience. In the United States of America, logit model was used by Nitin and Shui-Yan (2002) in their study to associate various factors to loan default and found that loan repayment was significantly influenced by entrepreneurs' businesses and borrowing experience in the same zip code as the lending agency at I and 5\% respective error levels.

Households demands has a coefficient of 0.151 (p-value $=0.012$ ) and a t-value of 2.379. This implies that the household demands have a positive and significant impact on table banking loan default rate. Similarly, Ugbomeh et al (2008) examined loan repayment performance determinants among women self help groups and revealed that women farmers' loan repayment performance was significantly and negatively affected by household size, interest rates and women as household heads. Sileshi, Nyikal and Wangia (2012) explored factors affecting smallholder farmers' loan repayment performance and revealed that non-defaulter and defaulter households varied significantly in terms of total land, total annual income, livestock units, technical assistance, distance from credit source, credit use experience and education. Moreover, education level, social ceremonies, crop and livestock disease and off farm income associated systematically with loan repayment. Though, amount of loan, family size and age did not differ significantly between the non-defaulters and defaulters. Women farmers' loan repayment performance was significantly and negatively affected by household size, interest rates and women as household heads but 
International Journal of Current Aspects in Finance, Banking and Accounting, Volume 4, Issue 1, 2022 PP 91-103, ISSN 2707-8035

significantly and positively affected by commitment to self-help groups and farm proceeds' price stability. In Anambra state in Nigeria, variables with significance bearing on credit repayment performance were identified by Arene (2012) and revealed that duration of farming experience, education level, income and loan size were statistically significant whereas household size and distance were not significant.

\subsection{Conclusions and Recommendations}

\subsection{Conclusions of the Study}

Based on the study findings, several conclusions have been drawn. First, the level of income has effect on Table banking loan default level amongst the women groups in Machakos county. Most of the women are either employed in formal employment or self-employed in their own businesses. The rate of formal employment or self-employment among women have an effect on the rates of loans uptake and defaults. The monthly earning in terms of income is a main factor that leads women to taking loans and influence the defaulting of the loans. Therefore, regular income rates affect the table banking loan default rate in women groups. The expenditure on households needs of bills and food lead women to default table loans in effort to meet their household needs. The second conclusion of the study was that woman financial literacy level has effect on Table banking loan default rate amongst women groups. There is a tendency of comparison of various financiers' terms and conditions prior to buying their services and products for business among women who have knowledge of financial handling exercises. This knowledge on the effect of inflation and interest rates affects the loan uptake among women who are financially literate. Financial goals aim on the business performance is often a concern which has a significant effect. Thirdly, borrowing experience among women affect Table banking loan default level. Women tend to borrow where they have borrowed more than three times. The study finally concluded that household demand has effect on Table banking loan default rate. Most of the women have at least three children in their households hence giving an average of four members in their households. This translates to high expenditure levels which in turn has effect on Table banking loan default rate.

\subsection{Study recommendations}

Based on the conclusions, several recommendations were made in terms of policy, practice and further research. The sections following explain the study limitations and recommendations. The women should be trained on how saving services and simple loans, can aid in improving the welfare of women particularly and the poor in general. The uptake of loans should be with the reason of income generation and not necessarily meeting the households' needs. This will ensure that the loans taken will be regenerated to assure repayment in time and minimize defaulting of the table banking loans. Thirdly the government should enhance entrepreneurship and financial management trainings including incorporating it through formal education. The women should engage in extra financial activities which will be sources of income. The uptake of loans should be with the reason of income generation and not necessarily meeting the households' needs. This will ensure that the loans taken will be regenerated to assure repayment on time and minimized defaulting of the table banking loans. The knowledge on inflation and interest rates that affects the loan uptake among women should be passed to women groups in order to elevate their literacy levels. The project focused on socio-economic factors influence on women's default table banking loans, therefore, other influential factors and disciplines should be studied to useful to reduce the defaulting of table banking loans. The study was limited in Machakos County. Low biasness can 
International Journal of Current Aspects in Finance, Banking and Accounting, Volume 4, Issue 1, 2022 PP 91-103, ISSN 2707-8035

be attained for all the Kenyan women groups, therefore, a study focusing on other locations and larger spheres of the population of the study should be done, that is, in county, regional and national levels.

\section{References}

Acquah, H. D., \& Addo, J. (2011). Determinants of loan repayment performance of fishermen: Empirical evidence from Ghana. Cercetări Agronomice în Moldova, 44(4), 148.

Addae-Korankye, A. (2014). Causes and control of loan default/delinquency in microfinance institutions in Ghana. American International Journal of Contemporary Research, 4(12), $36-45$.

Alvi, M. (2016). A manual for selecting sampling techniques in research.

Arene. C.J. (2012) Loan repayment and technical assistance among smallholder maize farmers in Nigeria. African Review of Money Finance and Banking. A supplement of Savings and Development Journal, Vol. I pp.64-72.

Armendáriz, B., \& Morduch, J. (2010). The economics of microfinance. MIT press.

Asetto, F. (2014). Effect of table banking on investment decisions of small and medium enterprises in Nairobi County. Unpublished MBA project. Nairobi: University of Nairobi.

Asetto, F. L. (2014). Effect of Table banking on the investment decisions of Small \& Medium Enterprises in Nairobi County. Unpublished MBA project). University of Nairobi. Bandura, A. (1997), Self-Efficacy: The Exercise of Control. New York: Freeman.

Berhanu, A. (2005). Determinants of formal source of credit loan repayment performance of smallholder farmers: the case of north western Ethiopia, North Gondar. Unpublished MSc. Thesis.

Bertrand, M., Karlan, D., Mullainathan, S., Shafir, E., \& Zinman, J. (2006). Pricing psychology: A field experiment in the consumer credit market. Manuscript, Princeton Univ.

Bharucha, J. P. (2019). Determinants of Financial Literacy among Indian Youth. In Dynamic Perspectives on Globalization and Sustainable Business in Asia (pp. 154-167). IGI Global.

Cheung,S and Sundaresan,S (2007) "Lending Without Access to Collateral, ATheory of MicroLoan Borrowing Ratesand Defaults"

Chowdhury, R., \& Dhar, B. K. (2012). The Perspective of Loan Default Problems of the Commercial Banking Sector of Bangladesh: A Closer Look into the Key Contributory Factors. University of Science and Technology Annual (USTA), 18(1), 71-87.

Cooper, D. R., \& Schindler, P. S. (2003). Business Research Methods (8 th edn.) McGrawHill: New York.

Davis, G. F., \& Cobb, J. A. (2010). Corporations and economic inequality around the world: The paradox of hierarchy. Research in Organizational Behavior, 30, 35-53.

Degryse, H., \& Van Cayseele, P. (2000). Relationship lending within a bank-based system: Evidence from European small business data. Journal of financial Intermediation, 9(1), 90-109.

Elstak, I. (2013). Connecting Algebra and Geometry for Extraneous Roots. Georgia Journal of Science, 71(2), 11.

Fantom, N., \& Serajuddin, U. (2016). The World Bank's classification of countries by income. The World Bank.

Hisrich, R., Langan-Fox, J., \& Grant, S. (2007). Entrepreneurship research and practice: a call to action for psychology. American psychologist, 62(6), 575. 
International Journal of Current Aspects in Finance, Banking and Accounting, Volume 4, Issue 1, 2022 PP 91-103, ISSN 2707-8035

Kariuki, C. M., \& Ngugi, P. K. (2014). The effects of Table banking On the Performance of Micro and Small Enterprises in Nairobi County. International Journal of Current Business and Social Sciences, 1(2), 339-360.

Kariuki, C. M., \& Ngugi, P. K. (2014). The effects of Table banking On the Performance of Micro and Small Enterprises in Nairobi County. International Journal of Current Business and Social Sciences, 1(2), 339-360.

King, K., \& McGrath, S. (2012, June). Education and development in Africa: Lessons of the past 50 years for beyond 2015. In Conference Proceedings: CAS (Vol. 50, pp. 6-8).

Kothari, C. R. (2007). Research methodology: Methods and techniques. New Age International.

Kwakwa, P.O. (2009). Causes of Non-Performing Loans at Bosomtwe Rural Bank Limited in Ghana .Unpublished Dissertation

Lumwamu, K., \& Murgor, B. (2014). How Joyful is changing the lives of rural women.

Marcelina, M. (2018). Assessing the Impacts of Social-Economic Factors on Loan Repayment Performance, A Case of CRDB and ACB Bank in Mwanza (Doctoral dissertation).

McGahan, A. M., \& Porter, M. E. (2016). How much does industry matter, really?. Strategic management journal, 18(S1), 15-30.

Mentzer, J. T., Stank, T. P., \& Esper, T. L. (2008). Supply chain management and its relationship to logistics, marketing, production, and operations management. Journal of Business Logistics, 29(1), 31-46.

Mian, A. (2018). The Credit-Driven Household Demand Channel.

Moullin, M. (2013). Defining performance measurement. Perspectives on performance, 2(2), 3.

Mugenda, O. M., \& Mugenda, A. G. (2009). Research methods. Quantitative and qualitative approaches.

Munguti, J. M. (2013). Determinants of Micro Credit Performance in Microfinances in Kenya. Unpublished Master" $s$ Thesis of Kenyatta University.

Mutiria, M. (2017). Factors Influencing Small And Medium Size Enterprises Access To Financing: A Case Of Kiambu County, Kenya (Doctoral dissertation, United States International University-Africa).

Mwangi, M. C. (2016). Effect of Loan Collection Procedures and Loan Default in Microfinance Institutions in Kirinyaga County. Global Journal of Management And Business Research.

Mwobobia, F. (2016). Contribution of table banking in the empowerment of women entrepreneurs in Kenya: a case of Eldoret Town. Journal of Business Theory and Practice, 4(2), 168.

Mwobobia, F. (2016). Contribution of table banking in the empowerment of women entrepreneurs in Kenya: a case of Eldoret Town. Journal of Business Theory and Practice, 4(2), 168.

Nguyen, C.H. (2007). Access to credit and borrowing behaviour of rural households in a transition. Paper presented at International Conference on Rural Finance Research Moving Results into Policies and Practices.

Nieman, G., \& Nieuwenhuizen, C. (2009). Entrepreneurship: A South African Perspective. Van Schaik.

Odame, H.H., Hefkin, N., Wesseler, G., Boto, I. (2002).Gender and agriculture in: the Information society intervention Service for National Agricultural research. Briefing paper No. 55. The Hague, the Netherlands: ISNAR

Ogato, G.S., Boon, E.K., Subramani, J. Improving access to productive resources and Agricultural services through gender empowerment: A case study of three rural communities in Ambo district, Ethiopia. Journal of Human Ecology, 2009. 27, No.2, 85 - 100. 
International Journal of Current Aspects in Finance, Banking and Accounting, Volume 4, Issue 1, 2022 PP 91-103, ISSN 2707-8035

Okunade, E. O. (2007). Accessibility of Agricultural credit and inputs to women formers of Isoya Rural Development Project. Research Journal of Agricultural and Biological Sciences, 2007, 3(3), $138-142$.

Oladeebo, J. O., \& Oladeebo, O. E. (2008). Determinants of loan repayment among smallholder farmers in Ogbomoso agricultural zone of Oyo State, Nigeria. Journal of Social Sciences, 17(1), 59-62.

Ombongi, G. O. (2015). The Relationship Between Financial Literacy And Loan Performance Amongst Customers Of Deposit Taking Microfinance Institutions In Kajiado County.

Oni, O. A., Oladele, O. I., \& Oyewole, I. K. (2005). Analysis of Factors Influencing Loan Default Among Poultry Farmers in Ogun State. Nigeria* Department of Agricultural Economics, University of Ibadan, Nigeria.** Department of Agricultural Extension and Rural Development, University of Ibadan, Nigeria. waleoniayo@ yahoo. com or oladele20002001@yahoo.com Manuscript received: May, 18, 2005.

Oni, O. A., Oladele, O. I., \& Oyewole, I. K. (2006). Analysis of factors influencing loan default among poultry farmers in Ogun State Nigeria. Journal of Central European Agriculture, 6(4), 619-624.

Orodho, A. J. (2009). Techniques of Data Analysis Using Statistical Package for Social Sciences (SPSS) Computer Package. Maseno, Kenya: Kanezja Publishers.

Roslan, A.H. \& M.Z. Abdkarim (2009). Determinants of Loan Repayment among Smallholder Farmers in Ogbomoso Agricultural Zone of Oyo State, Nigeria. Journal of social science 17(1): 59-62 (2008)

Sheila Arishaba L.(2011).Lending Methodologies and loan losses and default in a Microfinance deposit-taking institutions in Uganda. A case study of Finca Uganda Kabala Branch (MDI). Researh report presented to Makerere University, Uganda

Sileshi, M., Nyikal, R., \& Wangia, S. (2012). Factors affecting loan repayment performance of smallholder farmers in East Hararghe, Ethiopia. Developing Country Studies, 2(11), 205213.

Thrikawala, S. (2011). The determinants of entrepreneurial intention among academics in Sri Lanka.

Vonderlack, R. \& Schreiner, M. (2011). Women, Microfinance and Savings: Lessons and Proposals. Working Paper 01-5, Centre for Social Development, Washington University at St. Louis.

Warue, B.N., (2012). Factors affecting loan delinquency in Microfinance in Kenya. International Journal of Management Sciences and Business Research. Vol.1 Issue 12.

Waweru, C.(2010). Factors Influencing Repayment Of Bank Loans: A Case Of NIC Bank Limited, Nairobi Province Kenya.

Werre, C. A. (2014). Poverty alleviation in rural Kenya: A case study on women enterprise fund in Kanduyi, Bungoma County (Doctoral dissertation, Moi University).

This is an open-access article published and distributed under the terms and conditions of the (c) () \&) Creative Commons Attribution 4.0 International License of United States unless otherwise stated. Access, citation and distribution of this article is allowed with full recognition of the authors and the source. Copyright, content ownership and liability for content herein remain with the authors. 